\title{
Čím vším může být sociokulturní antropologie
}

\author{
Nikola Balaš
}

DOI: 10.21104/CL.2016.3.08

\section{What can sociocultural anthropology be?}

\begin{abstract}
First systematic efforts to establish sociocultural anthropology as an independent field appeared in Czech academia only after the year 1989. These efforts did not meet with much apparent success for a long time, and this provoked many authors who professed themselves as sociocultural anthropologists to criticize the unsatisfactory state of Czech anthropology. The most important of these criticisms are those by Zdeněk Nešpor and Marek Jakoubek. Both authors tried to demarcate the essence of sociocultural anthropology in their texts and oppose the fact that the name was often used as a label for approaches that had little to do with actual sociocultural anthropology. The present article aspires to a discussion with both of these authors. The main thrust of the argument lies in a conviction that if we accept Nešpor's and Jakoubek's demarcations of sociocultural anthropology, we paradoxically give up the best that sociocultural anthropology offers.
\end{abstract}

Keywords Sociocultural anthropology, anthropological theory, methods of research, history of anthropology.

Contact Mgr. Nikola Balaš, Fakulta humanitních studií, Univerzita Karlova, U Křiže 8, Praha 5 - Jinonice, 158 00, Czech Republic; e-mail: balas.nikola@gmail.com.

Jak citovat / How to cite Balaš, Nikola. (2016). Čím vším může být sociokulturní antropologie. Český lid 103, 473-490. doi:http://dx.doi.org/10.21104/CL.2016.3.08 
Stalo se už jakousi tradicí, že od počátku 90. let 20. století si čas od času někdo povzdychne nad neuspokojivou situací sociální a kulturní antropologie v Čechách. Není to překvapivé, protože systematická snaha udělat ze sociokulturní antropologie v Čechách autonomní obor začíná právě devadesátými léty. Je v tom jistá dávka ironie. Zatímco od začátku 70. let si na západ od nás čas od času někdo posteskl nad koncem antropologie vůbec, v Čechách vzdycháme nad tím, že tu pořádná antropologie ještě ani nezačala. ${ }^{1}$

Do tohoto diskurzu povzdechu patři i článek, který v roce 2004 vyšel v časopisu Český lid. Společně jej napsali Zdeněk Nešpor a Marek Jakoubek a nazvali ho příznačně: „Co je a co není sociální/kulturní antropologie“. Oproti jiným článkům vybočuje tím, že se jeho autoři snaží antropologii precizně definovat. Snad jako první polistopadoví zájemci o antropologii se systematicky ptají, co je zač ona sociokulturní antropologie, kterou bychom si i u nás tolik přáli mít.

Ani osm let po publikaci původního článku nebyli všichni ještě úplně spokojeni. Článek obou autorů sice podnítil bouřlivou a plodnou debatu, některé snad i přesvědčil, ale boj za antropologii ani v roce 2012 nebyl dobojován. Alespoň tak lze soudit z článku od Marka Jakoubka „Antropologie mezi pozitivismem a konstruktivismem" $z$ téhož roku. Článek jde v systematickém vymezení antropologie ještě mnohem dál a mnohem hlouběji než článek původní.

A zdá se, že dokonce ještě dnes je třeba systematicky pracovat na budování dobrého jména antropologie a trvat na jejím jasném vymezení. Hlavně druhý zmíněný článek byl diskutován v rámci debatního pásma Etno - Antro - Folk pořádaného v březnu 2016 studenty etnologie na FF UK. Cílem pásma bylo vyjasnit další směřování oboru a jeho případnou antropologizaci. Vzhledem k tomu, že se s článkem zacházelo jako s jakýmsi textem definujícím povahu oboru, který se na Filozofické fakultě má v následujících letech pěstovat, domnívám se, že si z tohoto důvodu zaslouží podrobnější rozbor.

Cílem mého př́spěvku je ukázat na sporná místa jak mladšího, tak staršího článku, nebot se domnívám, že mezi nimi existuje zjevná kontinuita. Oproti těmto článkům však není mým cílem hledání lepšího vymezení ve snaze autoritativně a exkluzivně vymezit sociokulturní antropologii. Mojí ambicí není ani přesměrovat obor jako takový. Spíše se domnívám, že snahou o precizní a exkluzivní definici sociokulturní antropologie ji paradoxně Marek Jakoubek se Zdeňkem Nešporem připravili o to nejlepší, co obor jako takový může nabídnout.

Plán mého příspěvku je následující. V první části se pokouším rozebrat základní pilíre, které podle obou autorů podpírají stavbu sociokulturní antropologie. Zaměřím se zejména na dva z nich - na stacionární terénní výzkum

1 Chci poděkovat Báře Strakové, Lence Brunclíkové, Lence Bednárové, Karolíně Drcmánkové a Liboru Bendovi a dvěma anonymním recenzentům za velmi pečlivé pročtení článku a za ještě cennější komentáře, které podstatně vylepšily jeho úroveň. Jak to tak bývá, ne vždy jsme se v našem pohledu na věc shodli, a moc se těším na případnou diskusi. 
a holistické hledisko. Druhou část věnuji dalšímu z pilírưu, kterým je striktní rozlišování mezi emickým a etickým hlediskem. Ve třetí části se pak zabývám specifickým pojetím sociokulturní antropologie jakožto sociálního konstruktivismu, se kterým přichází Marek Jakoubek.

\section{Co je a co není}

Jak se autoři snaží sociokulturní antropologii ve svém původním příspěvku definovat? Snaží se o to dvěma způsoby. Jednak ji definují negativně (čím není) pomocí vymezení antropologie vůči spřízněným vědám jako je historie, sociologie nebo etnologie. Druhý způsob spočívá v pozitivním vymezení (čím je) - představují její základní pilíře. Protože bych nerad vstupoval na pole sociologům, historikům a dalším, omezím se na kritiku druhého, pozitivního vymezení.

„Kulturní/sociální antropologie je na obecné rovině vymezena čtyřmi základními rysy,“ tvrdí autoři (2004: 66). Jedná se o (1) metodu stacionárního terénního výzkumu o ideální délce trvání alespoň jednoho roku, o (2) holistický př́istup ke studované skutečnosti, o (3) interdisciplinární přístup a o (4) důsledné rozlišování emického a etického přístupu.

Nakonec autoři dodávají, že „ani jeden z těchto př́istupů ... nelze označit za metodicky fundamentálně distinktivní pro kulturní/sociální antropologii. Pouze antropologie leží na jejich průsečíku, a je jím definována“ (2004: 69; 2006: 81). Lze tak například mít egyptologii, která se pokouší o holistické uchopení skutečnosti, razí interdisciplinární přístup a snaží se zachytit, co si mysleli staří Egyptané. Terénní výzkum mezi starými Egyptany lze ale provádět nanejvýš metaforicky.

\section{Víc než jen nálepka}

Potud se vymezení sociokulturní antropologie zdá dávat celkem dobrý smysl (a lze si asi představit i disciplínu, která splňuje všechna čtyři výše uvedená kritéria, ale která sebe samotnou neoznačuje za sociokulturní, natož za antropologii). Když se ale blíže podíváme na jednotlivé body, začne být situace poněkud složitější. Lze se ptát: Existuje nějaké antropologické dílo, které neleží na průsečíku všech čtyř ústředních rysů?

V případě důrazu na stacionární terénní výzkum může se leckomu pod vlivem tzv. „multilokální“ či „mnohamístné“ etnografie George Marcuse (1986: 171-173; 1995: 96-97) zdát, že autoři jsou ve svém přístupu poněkud staromódní a že zbytečně zdůrazňují stacionární povahu antropologického výzkumu. A není při tom třeba spojovat terénní výzkum na několika místech se studiem světového systému, ke které se Marcus hlásí. Jak naznačuje, paradigmatickou prací jsou Malinowského Argonauti Západního Pacifiku, kde lze stěží hovořit o studiu světového systému (Marcus 1995: 106). 
Nešpor s Jakoubkem by mě asi obvinili ze slovíčkaření. Zdůraznili by, že neměli na mysli ani tak výzkum v jedné lokalitě, jako spíše výzkum dlouhodobý a nepřerušovaný. A určitě nebudou považovat $\mathrm{z}$ principu za nevhodné, když antropolog v rámci výzkumu bude sbírat data na několika od sebe vzdálených místech.

Takovou námitku bych rád přijal, jenže v tom je menší háček. První bod, domnívám se, úzce souvisí s bodem druhým - s holistickým chápáním předmětu studia. Není překvapivé, že ve vymezení antropologie figurují tyto dva body pospolu. Asi by stálo za to si nejprve ocitovat, co vlastně oba autoři $\mathrm{k}$ antropologickému holismu říkají:
Předpokladem je, aby zkoumaný sociální útvar měl holistický charakter, byl kulturou či subkulturou ve smyslu systému, respektive subsystému společnosti nebo jiných společensky organizovaných útvarů, vyznačující se svébytným souborem hodnot, jazykem nebo jeho formou, „životním stylem“ atd. Pro jeho členy musí být typické, že z velké většiny zastávají jediný symbolický výklad světa, jsou stoupenci jediného symbolického univerza, zatímco jejich „okolí" svůj svět a život v něm implicitně či explicitně konceptualizuje odlišným způsobem. Popsanou sociokulturní autonomii přitom mohou vykazovat skupiny tak rozdílné, jako např́klad kmen Kwakiutlů $v$ Britské Kolumbii, obyvatelé izraelského kibucu nebo hokejoví fanoušci HC Sparta Praha. Jak uvedeno, znamená holistický přistup zřetel spiše $k$ celku, než k jeho jednotlivým částem a předpokládá, že celek je více než pouhý součet jeho jednotlivých částí. Antropolog tedy chápe kulturu jako systém, a to systém integrovaný, snaží se postihnout celkovou kulturní konfiguraci, popsat zvolený útvar jako strukturovaný a hierarchizovaný celek, nikoli jako soubor jednotlivin. Jednotlivé složky kultury jsou přitom vzájemně propojeny, přičemž význam jednotlivého prvku je v kulturním systému dán právě jeho vztahy k prvkům ostatním (byt nikoli pouze jimi). (2004: 67-68)

Staromódnost stacionárního výzkumu se zdá být umocněna staromódností holistického př́stupu. Autoři ve své definiční snaze kladou až příliš důraz na holistický charakter antropologického předmětu studia, kde lze jednotlivé celky studovat téměř jako hermeticky uzavřené. Tedy ne že by z principu nebylo možné pobývat rok v nějaké zapadlé vesnici a pátrat po tom, čím jsou obyvatelé této vesnice jako takoví specifičtí, odlišní a exotičtí. Jenže každý sociokulturní antropolog, který se pro takové studium rozhodne, by měl mít na paměti jednak nedostatky takové metody, a rovněž, že se tím sociokulturní antropologie nijak nevyčerpává z hlediska předmětu studia. Pro antropologii může být zajímavé studovat i vzájemnou interakci různých celků. 
Jde-li o nedostatky antropologického holismu, pak se jako účinná terapie nabízí sborník Anthropology and the Colonial Encounter (Asad 1973). Že antropologové nacházeli vedle sebe úhledně naskládané odlišné kultury jako různobarevné kamínky v mozaice, bylo do velké míry zapříčiněno kolonialismem, který v exotických lokalitách měnil tamní společnosti dávno před příchodem prvních antropologů. Když antropologové ve 20. století hovořili o tradičních domorodých kulturách a společnostech Navahů, Ndembuů nebo Nuerů, bylo to výsledkem již předcházejícího několikasetletého působení misionářů, obchodníků, armády nebo koloniální a státní správy (např. Clammer 1973). A antropologové mozaikovité vidění lokálních společenství do velké míry neproblematicky reprodukovali a přiživovali, a to nejen na papíře (např. Faris 1973).

Ne všichni antropologové ale museli čekat na Asadův sborník, aby si uvědomili, že Evropané mají velký vliv na podobu lokálních komunit. Zejména antropologové spojení s Manchesterskou univerzitou a s Rhodes-Livingstone Institute v Zambii byli schopni přesvědčivě ukázat, jak britská koloniální správa a pronikání peněžní ekonomiky měnilo lokální společenství, byt tyto změny nebyli schopni podchytit se vším všudy (viz např. Douglas 1963: 61-64, 128-129; Marwick 1948: 125-129; Marwick 1965: 53; Turner 1996: 133-136; Worsley 1957: 78-80; srov. Fardon 1999: 66-67).

Jinou programově inspirativní prací z té doby je sborník Ethnic Groups and Boundaries (Barth 1969a), který oproti drtivé většině předchozích antropologických studií cíleně vystupuje proti studiu diskrétních jednotek a zaměřuje se na interakce mezi jednotkami a na hranice mezi nimi. Co by si totiž hokejoví fanoušci Sparty počali bez hokejových fanoušků jiných týmů?

$\mathrm{Z}$ dějin antropologie lze zmínit i jiné klasické studie, které se nezaobíraly diskrétními celky, ale interakcí celků odlišných (Sahlins 1981), nebo dokonce makro perspektivou (Mintz 1985). ${ }^{2} \mathrm{Z}$ dějin antropologie by nám pak vypadl třeba i Claude Lévi-Strauss, který tvrdil, že rituály některých společností lze pochopit pouze na základě pochopení mýtů sousedních společností a naopak (Lévi-Strauss 2006: 208).

Leckdo může namítnout, že jde o další slovíčkaření, protože jako systém lze chápat nejen jednu společnost, ale i soubor několika dalších společností, nebo třeba i celý koloniální systém založený na výměně zboží, otroků a cukru. Nešpor s Jakoubkem mohou v tomto smyslu namítnout, že pokud studujeme fanoušky Sparty bez fanoušků jiných týmů, pak to znamená, že jsme ještě málo holističtí a musíme zahrnout fanoušky všech hokejových týmů v hokejové lize. Jenže i studium hokeje je samo málo holistické, protože také hokej je jedním ze sportů, které se nacházejí v poli všech sportů, a jak by asi zdůraznil Fredrik Barth, jako takový je hokej definován i hranicí s jinými sporty. Ve snaze být

2 Sahlinsova kniha Historical metaphors and mythical realities ani Mintzova Sweetness and Power navíc nesplňují další základní bod antropologické metody - terénní výzkum. 
holističtí tak proto musíme jít ještě o další úroveň výš. A nemusíme se zastavit ani na úrovni sportovních lig jedné země. Národní ligy totiž úzce souvisejí s národními týmy a asociacemi, které jsou na vyšší úrovni součástí celosvětového sportu. Až tehdy uvidíme celek, holos. Marek Jakoubek se Zdeňkem Nešporem se tak ve svém důrazu na holismus ničemu neproviňují.

Tohle by ale byla dost zvláštní dialektika. Důraz na holismus v takové podobě je ve skutečnosti odolný vůči jakékoliv kritice, protože pojem celku lze libovolně roztáhnout tak, aby zahrnul vše, co chceme, aby zahrnoval, a v takové podobě může sloužit nanejvýš jen eristickým úmyslům. Pokud holismem můžeme definovat libovolně velký celek, pak není jasné, co nám holismus jako takový o antropologii vlastně říká. Je to prázdný pojem.

Stojí za připomenutí, že když autoři hovoří o holismu, zmiňují sdílené hodnoty, sdílený jazyk, sdílený výklad světa nebo sdílené symbolické univerzum. Holistický charakter tak jakoby znamenal, že antropologie znamená studium fanoušků jednoho týmu, jednu vesnici, jeden kmen atd. Holismus tak má i konkrétní obsah. Jenže tady se můžeme vrátit už k výše zmíněným antropologickým studiím, které stěží naplňují holismus v tomto smyslu.

Dost možná měli autoři holistickým na mysli to, co je zjevné z druhé části citované pasáže. Když uvažujeme jako antropologové, nezajímají nás jevy ve své individualitě, ale v tom, jak jsou spolu vzájemně propojeny, jaký vytvářejí systém. To je jedno z klíčových stanovisek, které stojí u základů společenských věd. S takovým pojetím holismu souhlasit lze.

\section{Jak antropolog přechytračil domorodce a jak domorodec přechytračil antropologa}

Doposud jsem se snažil ukázat, že když vezmeme definiční rysy sociokulturní antropologie představené autory vážně, připravíme sami sebe o některé zajímavé přístupy. Ba co více, některé přední sociokulturní antropology budeme muset $\mathrm{z}$ doposud psaných dějin disciplíny vyškrtnout jako falešné sociokulturní antropology, nebo alespoň některé jejich práce musíme vyřadit ze zavedeného antropologického kánonu.

Přesunu se nyní - podle mého názoru - k nejzajímavějšímu a nejspornějšímu bodu celého vymezení antropologie, $\mathrm{k}$ důslednému rozlišování etického a emického přístupu. V původním článku oba autoři zdůrazňují, že je zapotřebí rozlišovat mezi oběma př́ístupy. Klíčovou maximou antropologického studia cizích kultur totiž je, že „vlastní interpretace kultury nesmí být prezentována jako popis z pozice [jejích] nositelů“ (Nešpor - Jakoubek 2004: 69). V dikci obou autorů znamená etický přístup, že se na studované lidi díváme jakožto badatelé pomocí badatelských konstruktů, hypotéz, kategorií atd. Naopak emický př́stup se snaží zachytit, jak sami studovaní lidé chápou svět a přemýšlejí o něm. Obecně dávám oběma autorům za pravdu. Důsledná refle- 
xe toho, co jako badatelé sami do svého chápání jinakosti vkládáme, je tím, k čemu bychom nejen jako sociokulturní antropologové měli směřovat. ${ }^{3}$

Ve skutečnosti si myslím, že vymezovat antropologii na průsečíku emického a etického přístupu není úplně produktivní jakožto definiční rys, protože zastírá pro antropologii podstatnější otázky, které celou dichotomii problematizují. Z líčení autorů se navíc i zdá, že pro sociokulturní antropologii je oproti jiným společenským a humanitním vědám hledisko aktéra rozhodující: „V kulturní/sociální antropologii se přitom projevuje jistá tendence upřednostňovat emický prrístup a ztotožňovat antropologii právě jen s emickou analýzou...“ (2004: 69) Nalezneme ale celou řadu dalších věd, které hledisko aktéra v potaz berou. I kvantitativní sociologické šetření klade koneckonců dotazovaným subjektům otázky na jejich názor. V historii, kde jsou zpravidla všichni respondenti už dávno mrtví, nám rovněž záleží na tom, co se například honilo hlavou vzbouřencům, kteří 14. července 1789 zaútočili na Bastilu. A i u částečně nediskurzivních věd, kterými jsou například dějiny umění, archeologie nebo studium materiální kultury, není z principu emické hledisko vyloučeno. I zde nás může zajímat, jak se autorův myšlenkový svět projevil v jeho materiální práci, nebo co nám předměty o svých tvůrcích a uživatelích prozrazují.

Hlavní otázkou pro sociokulturní antropologii i další přístupy beroucí v potaz hledisko aktéra, domnívám se, není primárně to, zdali vůbec klademe důraz na aktérské hledisko. Otázkou je, jak vůbec docházíme k tomu, že něco hlediskem aktéra je. $V$ doposud nepříliš dlouhých dějinách sociokulturní antropologie nalezneme celou řadu rozličných postupů, kterými se dá tento klíčový bod názorně předvést.

Možná to leckoho překvapí, ale i takový antropologický klasik jako James George Frazer, autor monumentální Zlaté ratolesti, který se považoval za civilizačně vyspělejšího a chytř̌ejšího, než byli jeho vybájení divoši, domnělé stanovisko divochů neignoroval. Když např́íklad Frazer píše: „Kdyby lidstvo bylo vždycky bývalo logické a moudré, nebyly by dějiny dlouhou kronikou pošetilosti a zločinu,“ (1994: 285) určitě z toho pro Frazera nevyplývá, že bychom měli jako antropologové naprosto ignorovat aktérské názory. Právě naopak, protože Frazer neignoroval to, co považoval za hledisko aktérů, mohl své bájné domorodce kritizovat z pozdně viktoriánských morálních standardů. Názory divochů jsou možná hloupé a pošetilé, ale jsou to jejich názory.

3 Zde vyvstává jedna základní potíž v zacházení s pojmem emický. Rozlišení mezi emickým a etickým přístupem, které zavedl americký lingvista Kenneth L. Pike, nemusí nutně znamenat totéž co „z hlediska aktéra“. Emický může znamenat i „z hlediska systému“ či „z hlediska struktury“ (srov. Dundes 1962: 101). Emický Ize samozřejmě chápat jako „z hlediska aktéra“ (např. Harris 1976: 329-330), přičemž může jít jako o hledisko aktérem uvědomované, tak o hledisko aktérem neuvědomované (Harris 1976: 338). Zdeněk Nešpor ani Marek Jakoubek ale emický přístup přesně nedefinují a není úplně jasné, co by měl znamenat. Některé možnosti nastíním později. 
Paradoxní je, že Frazer byl v jistém ohledu mnohem otevřenější ${ }^{4}$ aktérským výpovědím než britský funkcionalismus, který přišel po Frazerovi. Britský funkcionalismus byl ovlivněn současníkem evolucionismu a jeho velkým kritikem, francouzským sociologem Émilem Durkheimem. Je pravda, že si britští funkcionalisté Durhkeimovu sociologii poněkud zjednodušili a přizpůsobili ostrovnímu empirismu. Od Durkheima každopádně funkcionalisté převzali jednu z ústředních tezí jeho sociologie, a to tu, že badatel je v zásadě chytřejší než aktér - tedy, že je schopen vysvětlit jednání člověka lépe než daný člověk samotný, popř́padě že badatel je schopen lépe popsat společnost zvnějšku než příslušník této společnosti zevnitř (viz např. Durkheim 1969: 7; 1998: 79-80; srov. Winch 2004: 35). Tuto metodickou poučku nalezneme $\mathrm{v}$ dílech čelních představitelů britského funkcionalismu, u Alfreda Reginalda Radcliffe-Browna i u Bronisława Malinowského.

Dokud šlo o tzv. praktické jednání jako stavba chýše, okopávání sladkých brambor nebo plachtění na širém moři, byli funkcionalisté ještě ochotní připustit, že aktéři uvažují prakticky a řídí se zdravým selským rozumem. Ostatně kdyby se jím neřídili, asi by sociokulturní antropologie neměla co studovat. Situace ale začne být zajímavější u rituálních aktivit a u oněch zřejmě iracionálních přesvědčeních.

Radcliffe-Brown tvrdil, že si moc nepomůžeme s tím, když se aktérů budeme ptát na důvody rituálního jednání. Jak sám říká ve své Frazer lecture z roku 1939, jedná se o falešnou analogii s technickým jednáním (1952: 153). Otázka směřující na technický postup při okopávání sladkých brambor je kvalitativně odlišná od té, která zkoumá, proč se aktéři uchylují k rituálu.

Podle Radcliffe-Browna nám tak v zásadě zbývají dvě možnosti, jak rituál studovat. Bud' se zaměříme na studium významu symbolů, což je přístup, který se v antropologii plně rozvinul až v 60. letech 20. století. Nebo můžeme zkoumat skutečný vliv, který má provádění rituálů na danou společnost. Nutno zdůraznit, že v obou případech se Radcliffe-Brown vysloveně brání aktérským vysvětlením jakožto relevantním vysvětlením (1952: 153).

Byt' Malinowski razil poněkud odlišné pojetí funkcionalismu, je jeho teorie navzdory terminologii v mnoha ohledech s Radcliffe-Brownovou totožná. Stejně jako Radcliffe-Brown činí rozdíl mezi praktickým a rituálním jednáním. A stejně jako on tvrdí, že jen vědec je schopen dát v mnoha př́ípadech autoritativní vysvětlení, což samotní aktéři nemohou. Ti nám možná zprostř̌edkují svůj názor, ale to je tak všechno. Skutečné příčiny jejich jednání jim samotným zůstávají skryty (Malinowski 1992: 37-38).

Neadekvátnost aktérského vysvětlení se však týká pouze toho, co Malinowski nazývá náboženským jednáním. Zbylé dva druhy jednání- technické a magické - lze vysvětlovat s ohledem na názory aktéra, protože k obojímu 
se aktér podle svých vlastních slov uchyluje proto, aby ve svém konání uspěl. Aby to bylo ještě zajímavější, z hlediska skutečné efektivity magického jednání můžeme právem pochybovat o vysvětlení z hlediska toho, co úspěch zapříčiňuje, přesto nemůžeme pochybovat o tom, že jednání je skutečně efektivní. Magická zaříkávadla jsou jen psychologickým prostředkem dodávajícím odvahu a sebevědomí před nebezpečným podnikem (1992: 79). Malinowského slovy je pravda magie „zjevena nikoliv rozumem, ale hrou emocí s lidským organismem“ (1992: 87, překlad N. B.). Magie je účinná, protože reálně působí, čehož si je aktér na základě vlastní zkušenosti tak nějak mlhavě vědom. Bohužel ale vysvětlení její účinnosti s odkazem na nadpřirozený zásah neobstojí, protože nadpřirozené síly pro Malinowského antropologii neexistují.

Byt' z dnešního pohledu nám nezbyde než pousmát se nad některými myšlenkami Malinowského a Radcliffe-Browna, zprostředkovávají nám jeden základní poznatek o antropologii té doby. Už tehdy antropologové činili rozdíl mezi jednotlivými druhy aktérských výpovědí. Pokud bylo kontextem promluvy aktéra něco praktického, běžného, technického či každodenního, antropologové brali výpověd' vážně. Pokud bylo kontextem výpovědi naopak něco mystického, rituálního, magického nebo náboženského, antropologové zpozorněli. V žádném případě se ale nedá tvrdit, že by antropologové ignorovali všechny výpovědi aktérů a že by zároveň všechny výpovědi aktérů kladli na kvalitativně stejnou úroveň z toho důvodu, že by se jednalo právě o hledisko aktérů.

Zajímavé věci se v antropologii začínají dít od konce 50 . let, kdy je postupně opouštěno hrubé funkcionalistické stanovisko, které v případě magie a náboženství zdůrazňuje nezamýšlené důsledky jednání (jako je například stmelování společnosti prostřednictvím rituálního vyvolání emocí či nastolení psychické rovnováhy) a skepticky se staví k důvodům uváděným. Antropologové oživují některé zapomenuté pasáže z Durkheimovy sociologie a začínají se víc zabývat kolektivními reprezentacemi, užíváním symbolů a jejich významem. Antropologové obecně začínají svým aktérům více naslouchat.

Nutno podotknout, že obrat ke studiu projevů kolektivních reprezentací nebyl nějakou kvalitativní změnou. Chybně se hovoří o po sobě následujících paradigmatech strukturálního funkcionalismu a symbolické antropologie. Ve skutečnosti šlo zpravidla o tytéž antropology, kteří se jen začali věnovat novým tématům. Ti starší svůj předcházející zájem o sociální strukturu nijak neopustili, a ani mladší generace se studiu sociální struktury nebránila. Ba naopak - chceme-li pochopit systém symbolů nebo kolektivních reprezentací, musíme sociální strukturu poznat. Musíme zjistit, jaké existují v dané společnosti vztahy, jaký má daná společnost příbuzenský systém nebo jak je struktura ovlivněna ekologickými cykly, ${ }^{5}$ nebo dokonce lidskou tělesností, jak je v ní rozdělena moc nebo jaký praktikují daní lidé způsob obživy. Různými

5 Speciálně se na vztah životního prostředí a společenského uspořádání zaměřovaly některé proudy americké kulturní antropologie. Ty však zde ponechám bez diskuse. 
způsoby promýšlené vztahy mezi kolektivními reprezentacemi, symboly, sociálním životem a různými proměnnými nalezneme v dílech prominentnějších antropologů té doby - například u Mary Douglasové nebo Victora Turnera. Že je nutné brát v potaz vzájemnou souvislost společenského uspořádání bylo běžné i u autorů, kteří nebývají do proudu symbolické antropologie řazeni (srov. Barth 1969b: 29).

Tolik k intelektuálnímu klimatu sociokulturní antropologie od konce 50. let. Pojd'me se podívat, jak jinak se ještě dá s aktérskými výpověd'mi zacházet. Někteří antropologové v té době, Edmund Leach, Raymond Firth nebo John Beattie, experimentovali s tezí, že výpovědi a jednání s mystickým nebo iracionálním prvkem nelze brát doslova. Na jednu stranu uznávali, že z vědeckého hlediska jsou výpovědi o čarodějnicích požírajících zevnitř vnitřnosti svých obětí během spánku holým nesmyslem. Na druhou stranu ale naznačovali, že výroky o čarodějnicích, božstvech, totemech a jiných nadpřirozených bytostech, amuletech a silách je možná chybné chápat doslovně. Naopak, tyto výpovědi bychom měli chápat symbolicky (Jarvie - Agassi 1970: 180-190; Lukes 1970: 195-197). ${ }^{6}$

Symbolický přístup má lehce paradoxní nádech. Zjednodušeně řečeno, ve snaze zachránit aktéra nařčeného z iracionality tito antropologové tvrdili, že aktéři vlastně míní něco jiného než říkají. Kdybychom totiž aktéry chápali doslova, upřeli bychom ve skutečnosti jejich tvrzením z určitého úhlu pohledu pravdivost. Obvinění z čarodějnictví není primárně přitakáním nevědeckému pohledu na svět. Jedná se například o symbolické vyjádření sociálních vztahů v dané sociální struktuře. Aktér je vlastně více básníkem než vědcem.

Je to něco jako když se mezi sebou lidé častují zvířecími nadávkami. Označení vůl neznamená to, že by inzultovaný jedinec byl zvířetem doslova. Ve skutečnosti se tím tvrdí něco úplně jiného. V každém případě by ale bylo hloupé se domnívat, že ten, kdo někoho jiného častuje zvířecí nadávkou, by nebyl schopný rozlišovat mezi zvířetem a člověkem. Přistupovat k některým výpovědím doslovně je stejně tak absurdní jako měřit délku na kilogramy.

Obdobný přístup lze ukázat i v nediskurzivní rovině rituálu. Ilustruje to např́íklad historka Lorny Marshalové zmiňovaná Mary Douglasovou v Čistotě a nebezpečí:

Jakmile skupinka!Kungů provedla svůj rituál, objevil se na obzoru mrak a vše se setmělo. Pak začalo pršet. Antropologovi, který se zeptal !Kungů, zdali si skutečně myslí, že jejich rituál přivolal déšt', se !Kungové vysmáli. (Douglas 2002: 72, překlad N. B.)

Rituály prováděné aktéry ve skutečnosti nemají za cíl ovlivnit běh př́rody, jak se například domníval Frazer (1994: 61-77). Rituály přivolávání deště 
slouží například tomu, že oddělují různá časová období, což ve světle poznatků moderní vědy nepůsobí už tak absurdně. Situaci snad lépe vystihuje citace Spencera a Gillena z Lévi-Strausse:

Mouchy a komáři představují takovou metlu, že je na první pohled těžké porozumět tomu, proč jsou predmětem slavností, jež mají zajistit jejich rozmnožování... Avšak nelze zapomínat, že komáři i mouchy, i když jsou sami o sobě odporní, jsou úzce spojeni s tím, co si domorodci strašně prejí v jistém ročním období, to znamená prudký déšt'. (Spencer a Gillen, citováno dle Lévi-Strauss 2001: 73)

Některé rituály nesouvisejí ani tak s tím, že by aktéři věřili v jejich účinnost (ačkoliv se to nevylučuje stejně jako představa, že můj oblíbený tým dostal gól, protože jsem zrovna v tu chvíli nesledoval obrazovku). Jedná se spíše o vyjádření rituálních postojů $\mathrm{k}$ tomu, co je $\mathrm{z}$ hlediska aktérů žádoucí a co vyjadřuje étos jejich společnosti (srov. Tambiah 1968: 200-201; Winch 1970: 106). Je to jako kdyby k nám přišel př́íslušník nějaké exotické společnosti a myslel si, že zdejší lidé mají představu, že nevypijí-li na Silvestra dostatečné množství alkoholu a neudělají při tom náležitý randál, budou se obávat toho, že nový rok vůbec nepřijde. Ale zkuste naprríklad neoslavit Silvestra. Svět kvůli tomu asi neskončí, ale úplně uspokojivý pocit z toho také není. ${ }^{7}$

Co když ale antropolog stanovisko aktéra nakonec přeci jen interpretuje chybně? Co když je symbolické hledisko neadekvátní a co když aktér skutečně věří, že Silvestr přináší nový rok? Obdobná debata tentokrát téma roli otce při početí dítěte v patrilineární společnosti se rozproudila mezi Edmundem Leachem a Melfordem Spirem. Zatímco Leach se domníval, že výroky o roli otce u Austrálců je zapotřebí chápat $\mathrm{z}$ hlediska jejich příslušného rituálního kontextu a interpretovat je symbolicky (Austrálci si jsou jinak role otce vědomi), domníval se Spiro, že je zapotřebí brát tyto výpovědi doslova jako výroky, které ve všech kontextech považují Austrálci za pravdivé. Jak říká Steven Lukes, dostáváme se na samý okraj debaty, protože zde stojíme před logicky neřešitelnou volbou. K přitakání jednomu či druhému stanovisku nás pak zpravidla vedou jiná vodítka než názory Austrálců na daný problém (pro shrnutí debaty viz Lukes 1982: 283-289).

Krátký exkurz měl demonstrovat, že debata v antropologii ohledně toho, co si aktéŕi myslí, se nevede na dělicí čáře mezi emickým a etickým přístupem, ale mezi zastánci různých interpretačních a explanačních strategií. A jak bystře dodává Lukes, a jak ještě uvidíme, ,je tu ještě celá řada dalších komplikací“ (1982: 290).

7 Nakolik je možné vůbec porovnávat rituály méně komplexních společností s těmi ve více komplexních, ponechávám stranou. K tomu např́iklad Turnerův esej „From liminal to liminoid“ (Turner 1982). 


\section{Nelehký úděl konstruktivismu}

Z předchozího líčení bychom si mohli vzít téměř až lynchovskou poučku, že výpovědi aktérů nejsou tím, čím se zdají být. Nebo alespoň vždy nemusí být. Zásadní otázkou není, jestli máme upřednostnit emický, nebo etický přístup. Zásadní otázkou je, jak s jednotlivými výpověd'mi aktérů naložit. Protože jedině prostřednictvím toho může dojít na otázku, co že si to aktéři asi tak myslí.

Předchozí nástin měl ve čtenáři zasít myšlenku, že k výpovědím aktérů lze přistupovat různě, přičemž jednotlivé příspěvky do metodologické debaty by bylo chybné chápat tak, že se jedná o principiálně neslučitelné př́istupy. Otázka, zdali je blíže pravdě racionalistický pohled na svět, který nepřikládá aktérským stanoviskům v otázkách náboženství velkou váhu, protože je bere doslova, nebo naopak zdali je pravdivý symbolický př́stup, který k aktérským stanoviskům není tak odmítavý, ale naopak je nebere doslova, je ve skutečnosti špatně položená. Tyto př́stupy totiž lze kombinovat během jednoho výzkumu. Je jen otázkou antropologické citlivosti a snad i jistého druhu badatelské virtuozity, jak s těmito interpretačními strategiemi naložit a jak je dál vhodně rozvinout.

Nicméně je podstatné si uvědomit, že je to vždy antropolog, který jednotlivým výrokům svých informátorů přikládá různou váhu. Koneckonců i tvrzení, že slovo aktéra je posvátné, je stanoviskem antropologa, nikoliv stanoviskem aktéra. A kdo určuje konečnou platnost hypotetického výroku aktéra: „Vše, co říkám, je pravda“ - aktér, nebo antropolog? I kdyby chtěl Marek Jakoubek nebo jím inspirovaný antropolog například naznačit, že to není ani jeden ani druhý a že se dostáváme na samý pokraj našich interpretačních možností, bylo by i toto stanovisko stanoviskem antropologické autority. Antropolog nemůže sám sebe z principu vymazat a je vždy konečnou autoritou (Clifford 1983: 140). Marek Jakoubek se Zdeňkem Nešporem samozřejmě tvrdí, že „Důsledný emický přístup totiž ipso facto není možný,“ (2004: 69) a dávají tak za pravdu tezi o antropologické autoritě. Nabízí se ale otázka, proč vůbec definovat antropologii jako vědu striktně rozlišující mezi emickým a etickým hlediskem, když emické hledisko není z principu možné.

V následujících odstavcích se zaměřím na specifické pojetí sociokulturní antropologie jakožto sociálního konstruktivismu, které nabízí Marek Jakoubek. Celou debatu ohledně emického přístupu představím ještě na jiné rovině.

Domnívám se, že ač Marek Jakoubek ve svém článku z roku 2012 užil termínu emický pouze jednou (2012: 94), staví své pojetí sociokulturní antropologie na něm a lze vysledovat jistou kontinuitu mezi článkem z roku 2004 a článkem z roku 2012. V novějším článku se častěji setkáme s pojmem sociální konstruktivismus. ${ }^{8} \mathrm{~V}$ novém pojetí lze načrtnout fundamentální rovnici: sociokulturní antropologie rovná se emický př́ístup rovná se sociální

8 Sociálním konstruktivismem zde míním postoj Marka Jakoubka. Je to název, který Marek Jakoubek pro své pojetí antropologie používá. Nemám v úmyslu zde rozebírat různé druhy sociálního konstruktivismu. 
konstruktivismus. V každém případě sociálně konstruktivistický př́ístup vyjadřuje přesvědčení, že pro sociokulturní antropologii je určující zjistit, co si antropologem studovaní lidé myslí a jak přistupují ke světu.

Aby Marek Jakoubek představil základní konstruktivistické stanovisko sociokulturní antropologie, srovnává ji s etnologií. Srovnání se nabízí samo, protože obě vědy mají totožný předmět zájmu - lidské skupiny. Zatímco ale etnolog mapuje dějiny nějaké lidské skupiny, například Vojvodovčanů, jejich předků a potomků, snaží se antropolog postihnout, jaké je to být takovým Vojvodovčanem. Pokud pro svůj výzkum používá etnolog vzpomínky informátorů, tak je v každém př́ípadě na místě obezřetnost (2012: 84). Lidská pamět není nejlepším zdrojem pro historický výzkum a lidé vám z rozličných pohnutek celou řadu věcí zatají. Je pak zcela na etnologově profesionalitě, aby sebral co nejvíce materiálu, který pečlivě zanalyzuje a přijde s verdiktem o historické pravdě. Výpovědi aktérů jsou tak pro etnologa často jen prostředkem k nalezení historické pravdy. Vzhledem k ní mohou být výpovědi informátorů irelevantní (2012: 74).

Sociokulturní antropologie podle Marka Jakoubka ale postupuje jinak. Sociokulturního antropologa nezajímá žádná dějinná pravda. Zajímá ho, jak jeho Vojvodovčané vidí svět a popřípadě jakou mají vlastní verzi dějinné pravdy, která může být se skutečnou dějinnou pravdou v rozporu. V antropologově zájmu v každém případě není usvědčovat svého informátora $\mathrm{z}$ nevědomosti (2012: 74, 84). Naopak, antropolog se snaží ukázat to, co si Vojvodovčan o světě myslí a jak se to promítá v jeho každodenním životě: „Antropolog tvrdí, že pokud se (ex)Vojvodovčané za přímé potomky pobělohorských exulantů sami považují, tak jimi jsou.“ (2012: 91, kurzíva M. J.) To je pozice sociální antropologie (2012: 95-96). Být dobrým Vojvodovčanem zároveň neznamená být dobrým dějepiscem (či etnologem), stejně jako být dobrým křestanem neznamená být dobrým teologem.

A zatímco v prí́padě etnologie má poslední slovo badatel, v případě sociokulturní antropologie je to aktér. Pokud nějaký Vojvodovčan tvrdí, že je někým, kým podle etnologa není (protože etnolog ví, jak to bylo ve skutečnosti), pak to podle antropologa, není žádnou překážkou: „pokud lidé věří, že něco je pravda, pak to je pravda, resp. z premisy, že informátoři se nikdy nemýlí; mají své důvody myslet si to, co říkají“ (2012: 90-91, kurzíva M. J.). To je podle Marka Jakoubka pozice sociálního konstruktivismu, která je zároveň pozicí antropologie $(2012: 89,91)$. A to bez ohledu na historickou pravdu, která je se stanoviskem (ex)Vojvodovčanů v rozporu. ${ }^{9}$

Základní obtíž článku, kterou sdílí s textem z roku 2004, spočívá v tom, co je vydáváno za emický př́istup, respektive za přístup sociálního konstruktivismu. Z líčení Marka Jakoubka se mi nezdá, že by svůj postoj jednoznačně definoval.

9 Toto se zdá být v rozporu s tím, co Marek Jakoubek psal v roce 2005 v souvislosti s porozuměním romské kultuře: „Z uvedeného též vyplývá, že dané kultuře může badatel porozumět lépe než její nositelé ..." (2005: 213, kurzíva původní) 
V jeho textu objevíme podle mého názoru dvě různá pojetí. První se zaměřuje na studium toho, s pomocí jakých kategorií lidé o světě přemýšlejí. Odhalíme ale ještě jedno, silnější pojetí - směrodatné je to, co nám studovaní lidé ř

Na výše uvedených úryvcích lze velmi dobře ukázat, že Marek Jakoubek tato dvě pojetí dost dobře nerozlišuje. Emické může být to, co lidé tvrdí (ř́íkají), nebo to, co si lidé myslí (věří/považují/myslí). To jsou ale dvě absolutně odlišné věci. Není žádný spor v tvrzení, že člověk může něco říkat a něco jiného si myslet. Budeme-li tedy považovat aktérské výroky v každém případě za pravdivé, nikdy se třeba nedobereme toho, co si aktéři vlastně myslí.

Není vyloučené, že Marek Jakoubek měl při psaní svého článku na mysli filozofický problém autority první osoby. Jinými slovy, pokud nám nějaký mluvčí něco říká, pak tento mluvčí přesně ví, co nám chce říci a oproti svým posluchačům má ke své výpovědi privilegovaný přístup (Davidson 2004: 2122). Jako antropologové bychom měli napnout všechno své úsilí k tomu, abychom stanovisko první osoby co nejvěrněji reprodukovali. V každém případě se ale Marek Jakoubek na filozofické debaty ohledně tohoto problému neodkazuje. A navíc, ani Davidsonovo stanovisko není s naším problémem v rozporu (Davidson 2004: 21). To, že aktér ví, co nám svými slovy tvrdí, nijak neznamená, že by nám automaticky říkal to, co považuje za pravdivé.

Na nabízeném konstruktivistickém př́istupu je samozřejmě hezké, že je symetrický a že všem aktérským výrokům měří stejnou měrou a bere je vážně (z čehož by si mohl vzít př́iklad nejeden politik). Jenže nemusí jít ani o složité otázky týkající se náboženství a lidské racionality, abychom si uvědomili, jak ř́iká Lukes, že je tu celá řada dalších komplikací. Jednou z nich je, že takto pojatý sociální konstruktivismus nerozlišuje různé druhy promluv. Je stanovisko aktéra stanoviskem faktickým? Je to stanovisko normativní? Nebo je to snad př́ikaz? Nebo snad je to nějaké smíšené stanovisko (např. Gellner 2001: 46)? Aktér nám ke každé své výpovědi nepřidá vysvětlující klauzuli. Co aktér dělá a říká musí v mnoha případech antropolog odvodit z kontextu. Jenže v intencích Marka Jakoubka tím antropolog překračuje svoji badatelskou pravomoc, protože o aktérech říká něco navíc a chová se jako klasický pozitivista (2012: 91).

Vratime se na chvíli ještě k Austrálcům neznajícím biologickou roli otce. Lukes nabízí jednu zajímavou možnost. Co když se v jejich případě stane antropolog obětí žertu (Lukes 1982: 291)? Co když je z legrace antropolog Austrálci systematicky uváděn v omyl? Konstruktivistický přístup, že pravda je to, co aktér tvrdí, by doveden do důsledku znamenal, že antropolog se stává obětí žertu až ve chvíli, kdy mu žert potvrdí sám aktér. Ale to kazí veškerou legraci, protože jak víme, vysvětlovat vtip je jako pitvat žábu. Zjistíme sice podstatu věci, ale pacient během operace zemře.

Obdobně je na tom i rituál uctívání komárů, který v sobě může skrývat i jisté tragikomické přitakání svému údělu. Skrze sužující hmyz je oslavována žádoucí plodnost. Ale i tohle je antropologicky pochybné stanovisko, 
minimálně do té doby, než se nám o svém tragikomickém údělu vyzná sám aktér (srov. Sperber 1982: 152-153).

A lze jít ještě dál. Jak zacházet s tím, co řečeno není? Jak zacházet s tajemstvím? Jak zacházet se lhaním? Jak zacházet s nevědomostí a zapomínáním? Není vhodné odlišovat od sebe jednotlivé výroky v závislosti na tom, kdo je pronesl a při jaké příležitosti je pronesl? Jakou koherenci vlastně můžeme připisovat aktérskému pohledu na svět? Co dělat s protimluvy? A znovu - musíme vše, co si aktéři myslí, odvozovat z toho, co nám aktéři řeknou? Kolik antropologických domněnek vůbec nepochází z toho, co bylo aktéry vyřčeno? To vše jsou otázky, které jsou v dosavadní antropologické tradici široce tematizovány. Konstruktivistické stanovisko, alespoň tak jak je autorem prezentováno, nám oproti zavedené antropologické moudrosti bere $\mathrm{z}$ ruky všechny výzkumné trumfy a zdá se bud' dělat $\mathrm{z}$ aktérů př́liš jednoduché bytosti, nebo $\mathrm{z}$ antropologa hlupáka. ${ }^{10}$

To nás přivádí k ještě jednomu problému. Sociokulturní antropologie je mimo jiné vědou o lidském chování a jednání. Antropolog nutně jen nezaznamenává aktérské pohledy na svět, ale může se snažit pátrat i po příčinách nebo neuvědomovaných důvodech lidského jednání. A když přijde na příčiny a neuvědomované důvody, bývá člověk velmi špatným diagnostikem sebe sama. Pokud bychom chtěli jen zaznamenat aktérský pohled na věc, pak bychom $\mathrm{z}$ antropologie měli navíc vyloučit veškeré př́istupy inspirované kognitivní vědou, marxismem, ekologií nebo psychoanalýzou. Ostatně, že sociální vědy jsou mnohem více než jen snahou zachytit skutečnost from the native point of view, namítal Peteru Winchovi už Alasdair MacIntyre (viz MacIntyre 1970). Možná proto Marek Jakoubek píše, že „mají své důvody myslet si to, co říkají“ (2012: 90-91, kurzíva N. B.). Sociokulturní antropolog ale nemusí hledat jen důvody, může pátrat i po př́čcinách.

Najednou vidíme, že se před námi rozprostírá celá řada vzrušujících otázek, které si můžeme jako sociokulturní antropologové klást. Najednou se tvrzení, že máme brát výpovědi aktérů vážně, zdá být když ne zavádějící, tak minimálně banální. A je překvapující, jaký velký humbuk lze kolem toho ztropit. Někteří antropologové se spokojí s tím, že Vojvodovčané věří tomu, že nad Vojvodovem přeletěl drak. Jiní se třeba mohou začít ptát: „Jak může rozumný člověk věřit v existenci draků? Nemyslím tím existenci ,před dávnými a dávnými časy', ale tady a ted', jen kousek odtud, co by kamenem dohodil“ (Sperber 1982: 150, překlad N. B.). A zvídavý antropolog se nemusí vydat jen cestou kognitivních studií. Ano, sociokulturní antropolog se neobejde bez toho, co mu aktéři o sobě a o světě řeknou, ale u toho nemusí dobrý sociokulturní antropolog nutně skončit.

10 Marek Jakoubek ve svém článku cituje Pavla Baršu a jeho pojetí sociálního konstruktivismu. Baršovo pojetí se nezdá být s mojí kritikou v rozporu, protože je představeno relativně široce, a dokonce se v něm hovoří o napojení diskurzivních aktů na nediskurzivní (2012: 92-93). Otázkou je, nakolik je stanovisko Pavla Barši kompatibilní se sociálním konstruktivismem Marka Jakoubka. 


\section{Závěr}

Mým cílem bylo poukázat na dva články v českém diskurzu o sociokulturní antropologii, které se tuto vědu snaží autoritativně vymezit. Snažil jsem se poukázat na slabá místa v argumentaci a ukázat, proč není štastné zasazovat se o propagaci sociokulturní antropologie formou exkluzivních definic. Tato snaha je podle mého názoru z principu odsouzena k nezdaru. Naopak si myslím, že bychom měli být ve svých přístupech otevřenější. Samotné dějiny sociokulturní antropologie ukazují, že je to spíše otevřenost než uzavřenost, která tuto vědu definuje.

Definice antropologie, o kterou se v roce 2004 pokusili Zdeněk Nešpor s Markem Jakoubkem podle mého názoru ze sociokulturní antropologie vyloučila některé klasické inspirační zdroje. A podíváme-li se na vymezení oboru, o které se pokusil Marek Jakoubek v roce 2012, stává se členství v klubu sociokulturních antropologů ještě exkluzivnějším. Nejen že jsou přes palubu hozeny př́ístupy hledající při vysvětlování lidského konání silám neuvědomovaným aktéry, jak činí různé školy inspirované Marxem a Freudem. Stejný osud stihne i kognitivní antropologii a kulturní ekologii. Zavržena jsou nakonec i zvučná antropologická jména. Po prkně se projde Malinowski následovaný celou školou sociální antropologie, kterou tak pracně stvořil svým heroickým nadáním. Na galeje jsou uvrženi významní antropologové jako Mary Douglasová, Victor Turner, Fredrik Barth, Ernest Gellner a Claude Lévi-Strauss. Tito antropologové jsou pokrokoví v tom smyslu, že aktérským výpovědím přikládají větší váhu než jejich ryze funkcionalističtí předchůdci, přesto ale mají neustálé nutkání hledat korelace mezi uspořádáním společnosti či lidské mysli na straně jedné a sdíleným vnímáním světa na straně druhé. Takovým je možné dát šanci na polepšení, byt se to nepředpokládá a v jejich případě je verdikt asi doživotní. Vedení na takové lodi přebírají badatelé jako Peter Winch, nebo pozdní Clifford Geertz, ${ }^{11}$ a palubu jim k tomu drhnou staří dobří evolucionisté. Paradoxem takto pojaté disciplíny (Jakoubek 2012: 100) je, že v ní není př́liš mnoho prostoru pro proklamovanou interdisciplinaritu, teoretickou pluralitu a multiparadigmatičnost (Nešpor - Jakoubek 2004: 68-70) sociokulturní antropologie, což je v rozporu s třetím pilířem sociokulturní antropologie definované autory.

Podržíme-li se definice etnologické metody Marka Jakoubka, vyplývá z toho, že velká většina autorů konvenčně označovaných za sociokulturní antropology byla ve skutečnosti etnology, protože stejně jako například Iva Heroldová (Jakoubek 2012: 74) šli mimo a nad rámec toho, co aktéři o sobě a o světě tvrdili. Jak už bylo řečeno jednou, dobrý antropolog nebere stanoviska aktérů na lehkou váhu. U toho ale nemusí dobrý antropolog nutně skončit. 
Antropologie, jak ji chápu, skýtá prostor pro větší množství přístupů, než ta, kterou místní akademické obci nabízí ve svých textech Marek Jakoubek, potažmo Zdeněk Nešpor. A to nejen pokud jde o zavedené př́stupy a postupy jako např́klad ty, které jsou společné autorům posledního, monotematického čísla časopisu Cargo (2015). Jak je vidět, antropologie [sic] nabízí prostor i pro studium aktérů nelidských. Na to mi možná Zdeněk Nešpor s Markem Jakoubkem namítnou, že nás to vrací do doby, kdy si v Čechách pro sebe nálepku sociokulturního antropologa osoboval kdekdo. Jenže si nemyslím, že bychom relativní otevřenost antropologie zajímavým otázkám a rozličným důmyslným přístupům měli směšovat s přístupem almost anything goes. Fušeřina nemá ve vědě, natož v sociokulturní antropologii místo. Otázkou pak je, jaké místo bude mít sociokulturní antropologie na FF UK.

\section{Červenec 2016}

\section{Literatura}

Asad, Talal (ed.). 1973. Anthropology \& the Colonial Encounter. London and Atlantic City, N. J.: Ithaca Press and Humanities Press.

Barth, Fredrik (ed.). 1969a. Ethnic Groups and Boundaries. The Social Organization of Culture Difference. Boston: Little, Brown and Company.

Barth, Fredrik. 1969b. "Introduction." In: Barth, Fredrik (ed.): Ethnic Groups and Boundaries: The Social Organization of Culture Difference. Boston: Little, Brown and Company: 9-38.

Cargo, Journal for Social and Cultural Anthropology. 2015. 12, 1-2: 1-173. Clammer, John. 1973. "Colonialism and the Perception of Tradition in Fiji." In: Asad, Talal (ed.): Anthropology \& the Colonial Encounter. London and Atlantic City, N. J.: Ithaca Press and Humanities Press: 199-220.

Clifford, James. 1983. On Ethnographic Authority. Representations 2, 2: 118-146.

Davidson, Donald. 2004. Subjektivita, Intersubjektivita, Objektivita. Praha: Filosofia.

Douglas, Mary. 1963. The Lele of the Kasai. London: International African Institute. Douglas, Mary. 2002 [1966]. The Purity and Danger. An Analysis of Concept of Pollution and Taboo. London and New York: Routledge.

Dundes, Alan. 1962. From Etic to Emic Units in the Structural Study of Folktales. The Journal of American Folklore 75, 296: 95-105.

Durkheim, Émile. 1969. Pravidla sociologické metody. Praha: Vysoká škola politická ÚV KSČ.

Durkheim, Émile. 1998. Sociologie a filosofie; Sociologie a sociální vědy. Praha: Sociologické nakladatelství.

Fardon, Richard. 1999. Mary Douglas: An Intellectual Biography. London and New York: Routledge.

Faris, James C. 1973. "Pax Britannica and the Sudan: S. F. Nadel." In: Asad, Talal (ed.): Anthropology \& the Colonial Encounter. London and Atlantic City, N. J.: Ithaca Press and Humanities Press: 153-170.

Frazer, James G. 1994. Zlatá ratolest. Praha: Mladá Fronta.

Geertz, Clifford. 1973. The Interpretation of Cultures. Selected Essays. New York: Basic Books.

Gellner, Ernest. 2001. Pluh, meč a kniha. Struktura lidských dějin. Brno: Centrum pro studium demokracie a kultury. Harris, Marvin. 1976. History and Significance of the Emic/Etic Distinction. Annual Review of Anthropology 5: 329-350. 
Jakoubek, Marek. 2005. Multikulturalismus vs. kultura (Na příkladu tzv. Romů a 'jejich' kultury). In: Hirt, Tomáš Jakoubek, Marek (eds.): Soudobé spory o multikulturalismus a politiku identit. Antropologická perspektiva. Plzeň: Vydavatelství a nakladatelství Aleš Čeněk: 198-235.

Jakoubek, Marek. 2012. Antropologie mezi pozitivismem a konstruktivismem aneb krátký diskurz na téma jedné věty Ivy Heroldové. Dějiny Teorie - Kritika 1: 69-100.

Jarvie, Ian C. - Agassi, Joseph. 1970. The Problem of the Rationality of Magic. In: Wilson, Bryan (ed.): Rationality. Oxford: Basil Blackwell: 172-193.

Lévi-Strauss, Claude. 2001. Totemismus dnes. Praha: Dauphin.

Lévi-Strauss, Claude. 2006. Strukturální antropologie. Praha: Argo.

Lukes, Steven. 1970. Some Problems About Rationality. In: Wilson, Bryan (ed.): Rationality. Oxford: Basil Blackwell: 194-213.

Lukes, Steven. 1982. Relativism in Its Place. In: Hollis, Martin - Lukes, Steven (eds.): Rationality and Relativism. Cambridge: The MIT Press: 261-305.

MacIntyre, Alasdair. 1970. The Idea of a Social Science. In: Wilson, Bryan (ed.): Rationality. Oxford: Basil Blackwell: 112-130.

Malinowski, Bronislaw. 1992. Magic, Science and Religion and Other Essays. Long Grove: Waveland Press.

Marcus, George E. 1986. Ethnography in the Modern World System. In: Clifford, James - Marcus, George E. (eds.): Writing Culture. The Poetics and Politics of Ethnography. Berkeley, Los Angeles and London: University of California Press: 165-193.

Marcus, George E. 1995. Ethnography In/ of the World System. The Emergence of Multi-Sited Ethnography. Annual Review of Anthropology 24: 95-117.

Marwick, Maxwell G. 1948. African Witchcraft and Anxiety Load. A Journal of Social and Political Theory 2: 115-129.
Marwick, Maxwell G. 1965. Sorcery in Its Social Setting: A Study of the Northern Rhodesian Cewa. Manchester: University of Manchester Press.

Mintz, Sidney W. 1985. Sweetness and Power. The Place of Sugar in Modern History. London: Penguin Books.

Nešpor, Zdeněk R. - Jakoubek, Marek. 2004. Co je a není kulturní/sociální antropologie. Český lid 91: 53-80.

Nešpor, Zdeněk R. - Jakoubek, Marek. 2006. Co je a co není kulturní/sociální antropologie po dvou letech. Závěr diskuse. Český lid 93: 71-85.

Radcliffe-Brown, Alfred R. 1952. Structure and Function in Primitive Society. Essays and Addresses. Glencoe: The Free Press.

Ryle, Gilbert. 2009. Collected Essays 19291968. London and New York: Routledge.

Sahlins, Marshall D. 1981. Historical Metaphors and Mythical Realities: Structure in the Early History of the Sandwich Islands Kingdom. The University of Michigan Press.

Sperber, Dan. 1982. Apparently Irrational Beliefs. In: Hollis, Martin - Lukes, Steven (eds.): Rationality and Relativism. Cambridge: The MIT Press: 149-180.

Tambiah, Stanley J. 1968. The Magical Power of Words. Man, New Series 3, 2: 175-208.

Turner, Victor W. 1982. From Ritual to Theatre. The Human Seriousness of Play. New York: Paj Publications.

Turner, Victor W. 1996 [1957]. Schism and Continuity in an African Society: A Study of Ndembu Village Life. Oxford and Herndon: Berg. Winch, Peter. 1970. Understanding a Primitive Society. In: Wilson, Bryan (ed.): Rationality. Oxford: Basil Blackwell: 78-111.

Winch, Peter. 2004. Idea sociální vědy a její vztah $k$ filosofii. Brno: Centrum pro studium demokracie a kultury. Worsley, Peter M. 1957. The Trumpet Shall Sound. A Study of "Cargo" Cults in Melanesia. London: MacGibbon \& Kee. 